Dr Srdjan Golubović, *

Full professor, Faculty of Law,

University of Niš
ПРЕГЛЕДНИ НАУЧНИ ЧЛАНАК

UDK: 336.221(4-672EU)

UDK: 339.924:061.1EU

Рад примљен: 14.03.2014.

Рад прихваћен: 08.04.2014.

\title{
FISCAL ASPECTS OF THE EUROPEAN MONETARY INTEGRATION ${ }^{* *}$
}

\begin{abstract}
Along with the introduction of the euro as a single currency, importance of respecting the fiscal aspects which determine longevity of the monetary arrangement is recognized. For this reason, although underdeveloped, the EU fiscal system provides mechanisms to ensure fiscal discipline among member states. In addition to the fulfillment of the convergence criteria which is a precondition for joining the monetary union, they include no bailout clause and monetary financing prohibition. Sovereign debt that escalated in 2010 showed all the imperfections of these arrangements and pointed to the need for introduction of new and more effective fiscal rules. With fiscal system of the European Union as a starting point, the paper analyzes instruments defined by the fiscal system of the Union, which purpose is to ensure fiscal discipline of the European Monetary Union member states. Last part of the paper analyze new fiscal rules introduced as a response to the debt crisis in the eurozone.
\end{abstract}

Keywords: European Monetary Union, fiscal system, Stability and Growth Pact, Fiscal compact.

\section{Introduction}

Creation of the European Monetary Union and the introduction of euro in 1999 as a single currency are certainly the greatest achievement of the European integration. Monetary sovereignty was transferred to the supranational level, meaning that the responsibility for conducting monetary policy of the European Union was transferred to the Eurosystem, which consists of the European Central

\footnotetext{
* golub@prafak.ni.ac.rs

** This paper is the result of the research project "Balancing the law in Serbia with the law in European Union", funded by the Faculty of Law, University of Nis, for the period 2013 - 2018.
} 
Bank (ECB) and the national central banks of member countries of the monetary union. Creation of the monetary union, however, has not been accompanied by the fiscal unification. The global financial and economic crisis has fully exposed all the flaws of existing institutional solutions. Contrary to expectations, member states have failed to maintain fiscal discipline and EU institutions failed to ensure compliance with established rules.

This paper discusses the fiscal aspects of creating monetary union of the EU member states. In this regard, we first analyze elements of the EU fiscal system and then point to the key instruments and mechanisms which should ensure fiscal discipline among member states. Finally, in the last part of the paper we consider rules of the new fiscal agreement, which was accepted by the member states in response to the debt crisis that has engulfed the European Monetary Union.

\section{Fiscal system of the European Union}

Creation of the European Economic and Monetary Union has not been accompanied by fiscal unification. This approach has been conditioned by the principles of subsidiarity, which according to Art. 5 (3) The Treaty on European Union (TEU) implies that "in areas which do not fall within its exclusive competence, the Union shall act only if and in so far as the objectives of the proposed action can not be sufficiently achieved by the member states, either at central level or at regional and local level, but can rather, by reason of the scale or effects of the proposed action, be better achieved at Union level."${ }^{11}$ Applicability of the principle of subsidiarity when it comes to conducting economic, and hence fiscal policy, was the subject of wider debate in economic theory (Inman, Rubinfeld, 1994: 159). Of all the offered answers the most acceptable seems to be one that links the application of this principle with the answer to question of whether decentralized economic policies generate significant spillover effects. If the answer is yes, than the next question relevant for the question of whether priority should be given to national or supranational approach refers to whether the market mechanism i.e. coordination mechanism is suitable to overcome these effects. Only if the answer is negative, it makes sense to continue consideration of a centralized approach to this segment of economic policy. Finally, the third question, before accepting a centralized approach, concerns the way decisions are made and the effectiveness of centralized decisions. Supranational approach is acceptable only if it results in more effective economic policy. From an economic point of view, application of the principle of subsidiarity is conditioned by the answers to these three key questions. Extensive approach, i.e. that primary

1 Treaty on European Union, Official Journal of the European Union, (O.J.), C 326/1, 2012. 
responsibility for the conduct of economic policy still belongs to the member states, came to the fore in the legislation of the European Union (EU), which tells us that when designing the institutional framework of monetary union prevailed principle that the management structure should be set up so that it is able to internalize all external effects at the level of member states.

The formation of a monetary union without centralized economic management (i.e. fiscal union) inevitably means higher direct and indirect spillover effects of economic policies of the member states, which put the need for their harmonization to the fore, particularly in the fiscal area. According to numerous studies, spillovers effects are largest especially in the case of fiscal policy (Eijffinger, Haan, 1999: 81-82). This means that fiscal difficulties of a member states of the European Monetary Union (EMU), in the conditions of integration of financial markets can easily spill over to the financial sector of all other member states, which could easily destabilize the whole euro area.

The risk of spillover of economic disorder to other member states that have sound public finances is all the greater because the European Monetary Union includes countries that do not meet the conditions of an optimal currency area. ${ }^{2}$ Beginning of the EMU was marked by the optimism that after nominal adjustment the process of real adjustment will follow among the member states. With the unification of the legal systems of the EU countries (particularly legislation regulating financial sector), differences that represents potential source of asymmetric disturbances would diminish. This is supported by the standpoint of representatives of optimal currency area theory that monetary union is a much more efficient way to organize a system of insurance against asymmetric shocks in relation to the uncertainty that brings the system of national currencies (Grauwe, 2004:105). This under the condition that institutional framework of monetary union secure full mobility of labor and freedom of movement of capital, and thereby mitigate the effects in a country hit by asymmetric disturbance.

The conduct of the single monetary policy and its effectiveness primarily depends on the support of fiscal policy. Establishment and maintenance of price stability is directly conditioned by the state of public finances. The ideal solution for the monetary union is to transfer responsibility for the conduct of monetary and fiscal policy to a supranational body. Due to political and constitutional limitations EU has adopted a specific form of fiscal federalism. These specificities are related to: 1) the allocation of fiscal jurisdiction between member states and the EU as a supranational community, 2) the EU budget, 3) public expenditure

2 In order to form optimal currency area, for the states involved in the monetary union it is necessary to fulfill criteria in terms of the mobility of labor and other factors of production, price and wage flexibility, liberalization, equalization of the rate of inflation and fiscal integration. 
and public revenue policy and, consequently, 4) uniqueness of fiscal policies in achieving allocation, redistributive and stabilization targets (Šimović, 2005:150).

Taking these limitations into account, it is understandable why the EU fiscal system is characterized by underdeveloped structure. The structure of the fiscal system of the EU consists of three segments, with the EU budget as the only instrument for the implementation of fiscal policy at the supranational level. Other segments of the EU fiscal system include a set of rules and arrangements through which member states harmonize and coordinate fiscal policy (Grgić, Bilas, Šimović, 2006:13). The second segment of the EU fiscal system refers to the harmonization of tax systems (Dimitrijevic, 2009:286). Although competence of the regulation of tax system belongs to member states, their sovereignty in this area is limited since EU with its legislation can affect the solutions contained in the fiscal system. Finally, the third segment is the introduction of supranational rules to ensure fiscal discipline among member states. Until the outbreak of the crisis in the eurozone, the main instrument with the purpose to prevent the occurrence of excessive deficit was the Stability and Growth Pact (SGP) ${ }^{3}$. This document specifies the excessive deficit procedure (Article 126. Treaty on the Functioning of the European Union (TFEU). ${ }^{4}$

As it was conceived, the fiscal system of the EU does not provide space for EU institutions to respond with fiscal transfers in the case of asymmetric disturbances and thus make the necessary adjustments in conditions where mobility of production factors and flexibility of wages are absent. It is entirely left to the member states which, if they are affected by the recession, can only rely on national fiscal policy. Elements of the EU fiscal system, fiscal rules and the rule prohibiting the takeover of debts, primarily have in focus the fiscal discipline of the member states, which is treated as an instrument for achieving the main objective of monetary union - price stability.

\section{Fiscal discipline in the EU}

Weaknesses arising from the fact that EMU does not meet the criteria of an optimal currency area, EU legislation has sought to overcome by setting clear criteria of convergence, each EU member state must fulfill if it wants to join the

3 Pact entered into force in 1999. Stability and Growth Pact consist of: Resolution of the European Council on the SGP; Council Regulation on the strengthening of the survellance and coordination of economic policies, however. 1466/97, Council Regulation on speeding up and clarifying the implementation of excessive deficit procedure, No. 1467/97, Official Journal L 209, 02/08/1997.

4 Treaty on the Functioning of the European Union (TFEU) „Official Journal of the European Union, (0.J.), C 326/1, 2012. 
monetary union. Nominal convergence criteria includes five quantitative indicators related to: convergence of price or the rate of inflation, fiscal convergence, fulfillment of requirements in terms of the amount of budget deficit and public debt, convergence of the exchange rate and interest rates. ${ }^{5}$ By defining the convergence criteria and introducing fiscal constraints over-expansionary fiscal policies of member states is prevented and negative spillover effects restrained, which could easily jeopardize the establishment of price stability as the primary objective of EMU member states economic policies.

Until the outbreak of the crisis in the eurozone, EU legislation anticipated two key elements that should stimulate member states to respect fiscal discipline: 1) no bailout clause and 2) monetary financing prohibition, that is, prohibition on the purchase of debt instruments of the member states, i.e. EU institutions.

A key anchorage of fiscal discipline in EMU are provisions of the TFEU, which were otherwise included in the Maastricht Treaty, containing a clause that prohibits the takeover of debts of member states by the Union. According to Article 125. of TFEU "The Union shall not be liable for or assume the commitments of central governments, regional, local or other public authorities, other bodies governed by public law, or public undertakings of any member state, without prejudice to mutual financial guarantees for the joint execution of a specific project. A member state shall not be liable for or assume the commitments of central governments, regional, local or other public authorities, other bodies governed by public law, or public undertakings of another member state, without prejudice to mutual financial guarantees for the joint execution of a specific project.

Prohibition on takeover of debts is directly related to the prohibition of monetary financing (financing deficit with the loans of central bank), contained in the last two Articles of the TFEU, which are also applied directly. First, there are provisions of Art. 123 which provides for the prohibition of lending by the ECB and the national central banks to member states and EU institutions. Mentioned article prohibits takeover of debt instruments by the monetary authorities of the EU institutions and member states. Secondly, Article 124. of the TFEU introduces another ban that strengthens fiscal discipline, related to the prohibition of privileged access to financial institutions, regardless of whether they are bodies of the Union or member states. Above provisions are oriented towards

5 Out of the eleven countries for which the Commission expected to join the EMU (Germany, France, Spain, Netherlands, Belgium, Luxembourg, Portugal, Finland, Austria and Ireland, during 1997 only Finland fulfilled all conditions, France and Luksemburg, joined by Ireland and Portugal in 1998. Other countries did not meet at least one criterion in 1997 and 1998. Convergence criteria were also relevant for the states that have later become members of EMU (in 2001 Greece, 2007 Slovenia, 2008 Cyprus and Malta, 2009 Slovakia, 2011 Estonia and in 2014 Latvia). 
stimulating budgetary discipline predicted in Article 126 (1), i.e. avoidance of excessive government deficit.

Above provisions are a key part of the Budget Code of European Union, which states that each member state is responsible for its public finances (Louis, 2010: 978). Neither the Union nor the member states can not be responsible for the liabilities of others member states. Assuming that only mature economies can become members of the monetary union and that the necessary adjustment efforts should be undertaken by each of the countries, TFEU preclude granting direct financial support to individual states should they suffer stress owing to membership in the monetary union (Stark, 2013:544). Thus, with the introduction of this clause in the primary law of the Union, financial markets are warned that each member state is left on its own when it comes to its public finances and that there are no implicit guarantees on the part of the Community or the member states (Smits, 1997:77-78). Therefore, the state can finance deficit by issuing bonds in the financial market, but under the conditions that correspond to its creditworthiness. If state with low creditworthiness, that is state which is behaving financially irresponsible, appear on the financial market it will result in a higher risk premium. The purpose of these provisions is that market assesses financial health of the state.

Introduction of the clause that prohibits the takeover of debts and deficit monetization prohibition mean that EU law has recognized the importance of fiscal discipline. However, this does not exclude the possibility to avoid these limitations. This primarily relates to the principle of solidarity provided for in Article 122. of TFEU, which provides the possibility of financial assistance from the Union if a member state run into difficulties caused by events that are beyond its control. ${ }^{6}$ There is also the possibility of indirect financial assistance. Rescue action (bail out) may occur in the secondary market, that is ex post, when central bank buys government bonds or ex ante, when central bank keeps interest rates low, trying to reduce the cost of interest payments. However, the crucial question is whether commitment to the preservation of price stability will be strong enough to withstand political pressure to support countries that confront the excessive burden of debt. In the past period it has been shown that some states are ready

6 Article 122 states: Without prejudice to any other procedures provided for in the Treaties, the Council, on a proposal from the Commission, may decide, in a spirit of solidarity between Member States, upon the measures appropriate to the economic situation, in particular if severe difficulties arise in the supply of certain products, notably in the area of energy. Where a Member State is in difficulties or is seriously threatened with severe difficulties caused by natural disasters or exceptional occurrences beyond its control, the Council, on a proposal from the Commission, may grant, under certain conditions, Union financial assistance to the Member State concerned. The President of the Council shall inform the European Parliament of the decision taken. 
to enjoy all the benefits of monetary integration, but not ready to take responsibilities that are essential for the functioning of the monetary union (Feldstein, 2013:106). In particular, it means that many eurozone member countries, even in the period of prosperity, did not manage to maintain a sound fiscal position in accordance with the rules of the EU fiscal framework. The result of this behavior is rapidly increasing levels of indebtedness in states with excessive consumption, especially in Greece, Ireland, Italy and Spain. Regardless of the increased risk for creditors, global financial markets did not react by increasing interest rates for the countries with growing indebtedness. Buyers of bonds issued by these states, ignoring the prohibition on the takeover of debts, started from the assumption that bonds issued by individual member states of the eurozone are equally secure as bonds of any other member state with significantly lower level of debt. Due to this perception of the financial market participants, interest rates on Greek and Italian bonds were slightly higher than the interest rate paid on the safest, German bonds. Before monetary unification, high budget deficits would lead to a higher interest rate or exchange rate depreciation. These changes in the market represented an alarm for the states to reduce their debts. With the creation of a monetary union such signals in the market were eliminated with the consequent trend of growth of public and private debts. Collapse of the U.S. financial markets in 2008 caused a serious global recession, which spilled over to other european countries, exacerbating their fiscal position. When markets finally recognized the risks associated with states with high indebtedness at the beginning of 2010, the interest rate on the bonds of these states began to grow vertiginously. Given the fact that most of the invested funds came from european banks, decline in the value of bonds affected the deterioration of their position. Confronted with the crisis, which also calls into question the survival of the eurozone, institutions of the Union have defined program whose basis represents the reversal of negative trends in the financial market, primarily with the intervention of the European Central Bank, debt restructuring and support for heavily indebted countries and amending the legal framework in a way that will ensure fiscal discipline of the member states.

From the very beginning of the crisis, European Central Bank has reacted decisively and quickly using standard and non-standard monetary policy measures. The first response to disturbances in the market was based on the assessment of medium-term risk compromising price stability in the euro area. ${ }^{7}$ At the same time, ECB opted for the non-standard monetary policy measures, in an effort to

7 The interest rate was reduced by 325 basis points between October 2008 and May 2009 and was not changed until the April 2011. In the same period, the main refinancing rate was $1 \%$, while the Euro overnight index average (EONIA - overnight index average is calculated as a weighted average of all overnight lending transactions in the interbank market) declined sharply, reaching a level of $0.3 \%$. 
encourage the inflow of capital into the banks, and to ensure the transmission of lower interest rates for households and businesses. The main non-standard measures in this context is to ensure bank liquidity at a fixed, low interest rate with the use of appropriate collateral. Also, ECB is engaged in the purchase of government bonds in an effort to curb the growth of interest rates on government bonds of some countries. The use of standard and non-standard measures by ECB brought expected results and relieve instability in the financial market.

\section{Fiscal rules in the European Union}

Key institutional deficiency, reflected in the lack of conditions for conducting a supranational fiscal policy, fully exposed by the global economic and financial crisis, EMU creators strive to overcome by improving existing and introducing new fiscal rules. Fiscal framework defined by TFEU and the Stability and Growth Pact (restrictions on the budget deficit and the public debt) is changed and amended to the new rules (Andjelkovic, 2013:187). Strengthening the existing fiscal framework of the European Monetary Union was achieved with the entry into force of a package of legislative measures (legislative changes) on December 2011. These new measures, known as the six-pack, include five new Regulations and one Directive. The most significant changes introduced by this package include:

a) Strengthening of the preventive measures. Amendments to SGP reinforce the obligation of member states to avoid excessive budget deficit (threshold is 3\% of GDP) and public debt growth above the threshold of $60 \%$ of GDP. Strengthening of the preventive measures involves effective budget control and better coordination of economic policies of the member states, in accordance with the Art. 121 of Treaty, with a aim to recognize the problem of excessive budget deficit in the early stage. Key changes in preventive measures of Stability and Growth Pact are related to greater transparency, obligation to set up medium-term budgetary objective (MBO), which must be evaluated on the basis of an overlall asessment with the structural balance as a reference, including the analysis of expenditure net of discretionary revenue measures. ${ }^{8}$ Certainly the most significant changes in the area of preventive measures are related to increase of the effectiveness of preventive measures. Failure to comply with the agreed principles by the specific member state leads to the recommendation of the EU Council on the necessity to implement appropriate corrective actions. Failure to comply with the recommendations entails appropriate consequences. If the state is a member of EMU, failure to take action leads, according to Art. 4 Regulations

8 Deviation from the medium-term budgetary objective or adjustment path towards it is possible only in exceptional circumstances and only under the condition that it does not jeopardize medium-term fiscal balance. 
no. $1173 / 2011$, to Council decision which asserts that such action is lacking. ${ }^{9}$ Within 20 days from the adoption of such decision Commission suggests Council to bring a decision to introduce financial sanctions against a particular country. Financial sanction is reflected in interest-bearing deposit amounting to $0.2 \%$ of its GDP in the previous year.

b) Strengthening of the corrective arm. Corrective mechanism is automatically activated in the event of observed significant deviations from the MTO or the adjustment path towards it. In addition to the rule relating to budget deficit, Pact amendments introduce another criterion, which refers to the amount of public debt. The reduction of the public debt, according to the Council Regulation no. $1177 / 2011$, shall be treated as one of the criteria for assessing the state of public finances. ${ }^{10}$ Member states of the euro area with the public debt that exceeds the reference value ( $60 \%$ of GDP) are required to reduce the amount by which their debt exceeds the referent value at least by $1 / 20$ years in the next three years. If they do not, excessive deficit procedure would be applied against them. EU Council, acting in accordance with the Art.126. of the Treaty on the Functioning of the EU, decides on whether an excessive deficit exists in the state that has already been deposited interest bearing deposit or in the state where Council, on the basis of recommendation of the Commission, established a serious violation of the obligations in terms of the budget deficit, the Commission shall, within 20 days of the decision, recommend the adoption of the decision which demands from the member state to place interest-free deposits. If, nevertheless, action aimed at eliminating excessive deficit is absent, which is asserted by the Council decision, the Commission shall, within 20 days, recommend to convert the non-interest bearing deposit into a monetary penalty.

Amendments of the Stability and Growth Pact include also the introduction of the early warning system of macroeconomic imbalances, taking into account internal (indebtedness of public and private sector, developments in the financial markets, unemployment rates and the like) and external indicators (as the current account balance, net investment position of the country, real exchange rate, price movements, etc) follow the trends in modern theory of public finance (Andjelkovic, 2009: 115). If it is concluded that a country is facing serious imbalance, Commission will prepare a detailed report on macroeconomic developments. Such report is prepared also in the case when there is a risk of the occurrence of

9 Regulation (EU) No 1173/2011 of the European Parliament and of the Council of 16 November 2011 on the effective enforcement of budgetary surveillance in the euro area, Official Journal of the European Union, L 306/1.

10 Council Regulation (EU) No 1177/2011 of 8 November 2011 amending Regulation (EC) No $1467 / 97$ on speeding up and clarifying the implementation of the excessive deficit procedure, Official Journal of the European Union, L 306/33 
unexpected disturbances that require detailed analysis. On the basis of detailed analysis, if Commission considers that the member state is facing an imbalance, it notifies the European Parliament, the Council and the Eurogroup. The Council, on the base of a proposal of Commission, gives recommendations to member state on the main directions of economic policy. Finally, six-pack introduces periodic surveillance over the economic policies and the state of public finances. ${ }^{11}$

In an effort to overcome the consequences of the current crisis of eurozone and create an institutional framework that will prevent their occurrence in the future, institutions of the EU accepted the Treaty on Stability, Coordination and Governance in the Economic and Monetary Union (TSCG) in 2012. Its central part is the Fiscal Compact, which aims to foster fiscal discipline, notably in the euro area, building on and enhancing the reinforced SGP. Its key elements include: 1) balanced budget rule including an automatic correction mechanism and strengthening of the excessive deficit procedure, 2) The obligation of contracting parties to ensure obedience to fiscal rule at the national level, 3) Supra-national control of member states budget through strict application of the excessive deficit procedure, including the application of sanctions and control by the European Court of Justice.

1) The biggest novelty is the introduction of "golden rule" to ensure fiscal discipline among member states. Under this rule, budget of the member states should be balanced or in surplus. Unlike the revised SGP, which determined the obligation of member states to avoid excessive deficits, the new fiscal treaty set stricter rules since it requires a balanced budget or budget surplus. Exceptionally, adopted budget rule allows the possibility of a structural budget deficit that can not exceed $0.5 \%$ of GDP for the states where the proportion of debt to GDP exceeds $60 \%$, or $1 \%$ for the countries with the share of debt below the reference value. The new fiscal treaty has largely taken solutions provided in the SGP. Golden budget rule is applied together with the remaining three fiscal rules, with the rules related to the amount of debt and the budget deficit already accepted by the Maastricht Treaty, and the rule of reducing public debt by $1 / 20$ a year taken from the Regulation 1177/2011, that amended Stability and Growth Pact.

2) The application of fiscal rules at the national level. Contracting parties are obliged, at the latest one year after the entry into force of this Treaty, to incorporate balanced budget rule into the national legislation and strengthen its obeisance through provisions of binding force and permanent character, preferably constitutional, or otherwise guaranteed to be fully respected and adhered to

11 Regulation (EU) No 1175/2011 of the European Parliament and of the Council of 16 November 2011 amending Council Regulation (EC) No 1466/97 on the strengthening of the surveillance of budgetary positions and the surveillance and coordination of economic policies, Official Journal of the European Union, L 306/12. 
throughout the national budgetary processes. According to Article 3. of TSCG, contracting parties are obliged to take the necessary measures in order to ensure convergence to the appropriate medium-term objective. Proposition of the time frame to achieve convergence is determined by the Commission, assessing for each country the risk of sustainability. Of course, realization of these goals presuppose the existence of economic stability. To ensure adequate flexibility Fiscal Compact provides an output clause. Article 3. (3) provides a temporary exception from the rule of a balanced budget if unexpected circumstances occur, defined by the agreement as extrinsic event outside control of the signatory states. ${ }^{12}$ In addition, each state is required to define the corrective mechanism that is automatically activated in the event of significant deviations from the implementation of the medium-term objective. ${ }^{13}$ If member states do not incorporate balanced budget rule and correction mechanism into their national law, Art. 8 of TSCM, fiscal agreement provides for the possibility that member states, on the basis of the report of Commission or on its own initiative, take action before the European Court of Justice, whose decision oblige affected country to take necessary measures to comply with judgment within a specified period.

3) Supranational control of the member states budget through the strict application of the excessive deficit procedure, including the application of sanctions and control by the European Court of Justice. The most significant changes when it comes to supranational control refers to the excessive deficit procedure. State subjected to an excessive deficit procedure shall put in place a budgetary and economic partnership program, including a detailed description of the structural reforms which must be put in place and implemented to ensure an effective and durable correction of its excessive deficit. The content and format of such programs shall be defined in European Union law (article 5 TSCG). The program shall be submitted to the Commission and the Council for approval and monitoring of its implementation within the framework of multilateral surveillance provided by the SGP.

Another important novelty concerns the introduction of a quasi-automatic sanctions for states that do not meet criteria in terms of the amount of deficit. Imposition of sanctions is facilitated by introducing categories of reverse majority voting. Treaty on the Functioning of the EU (Article 126. (13)) required a qualified majority for the adoption of sanctions against a particular state, while

12 By defining exceptional circumstances as events that are extrinsic and acting outside state control, the Agreement provided that they have a significant impact on the financial position, that is they can cause serious economic consequences.

13 Each Member State at national level defines corrective mechanism based on the principles laid down by the Commission, particularly in relation to the nature, scope and time frame of the implementation of corrective actions. 
the fiscal agreement require qualified majority for the decisions to not apply sanctions. Certainly the biggest novelty is the judicial review of compliance with the provisions of a fiscal agreement. By adopting fiscal agreement, EU Court of Justice receives a significant role in monitoring the implementating the fiscal rules. According to Art. 8 of TSCG, signatory states shall, on the basis of the Commission report or independently of this report, present the case before the Court of Justice upon estimates that signatory state has failed to fulfill obligation to include rule on budgetary balance in national legislation in accordance with Art. 3 (2) TSCG.

The Court's decision is mandatory for the parties involved, which are obliged to take appropriate measures to enforce the decision of the Court at a certain time frame. If the signatory state, on the basis of self-assessment or the assessment of the Commission, considers that another member state has not taken necessary measures for the fulfillment of the Court decision, it may bring the case before the European Court of Justice and demand the introduction of financial sanctions on the basis of criteria established by the Commission, in accordance with the Article 260 of the Treaty. ${ }^{14}$ If the Court confirms that member state has not acted in accordance with its decision, it may be ordered to pay a lump sum or penalty in accordance with the circumstances, with the imposed sanction that can not exceed $0.1 \%$ of GDP. If sanction is imposed on the eurozone state, monetary amount has to be paid to the European Stability Mechanism; in other cases payments are made to the general budget of the European Union.

\section{Conclusions}

Debt crisis has exposed all the flaws of the European Union fiscal system. The fiscal system of the EU is not only underdeveloped but also mechanisms aimed at preserving the fiscal discipline of member states proved totally ineffective. Faced with the crisis, which calls into question the survival of the eurozone, EU institutions have defined a program whose basis is the reversal of the negative trends in the financial markets, primarily through the intervention of the European Central Bank, debt restructuring and support for heavily indebted countries and amending the legal framework in order to strengthen fiscal discipline of member states. Fiscal treaty not only introduces new fiscal rules in the EMU, but also imposes certain restrictions to national fiscal policies. Agreement brings following elements into the fiscal framework: budgetary "golden rule“, whose application is expected to establish fiscal discipline in the eurozone;

14 Article 260 (2) states: If the Court finds that there is an infringement it may impose a lump sum or penalty payment on the Member State concerned not exceeding the amount specified by the Commission. The payment obligation shall take effect on the date set by the Court in its judgment. 
application of the "golden rule" on a national level through debt brakes and supranational control of member states budget through strict application of the excessive deficit procedure, including application of sanctions and control by the European Court of Justice.

In the following period, eurozone will face two serious challenges. The first, otherwise inherent to all debt-ridden countries, refers to the consolidation of public finances and restoring economic growth. Another challenge relates to the strengthening of the institutional basis of monetary union, which would create the conditions for avoiding problems in the functioning of the monetary union, which were evident during debt crisis. Former experience tells us that in a monetary union it is not possible to simultaneously achieve fiscal sovereignty of member states, no bail clause and independence of the monetary authorities. Persistence in application of former solution means that in the future monetary union would be forced to sacrifice no bail clause, or monetary policy independence.

Of course, the takeover of debts can not proceed indefinitely, nor is it possible that monetary policy which is subordinated to fiscal policy ensure price stability. Treaty on Stability, Coordination and Governance in the Economic and Monetary Union limited fiscal autonomy of the member states. Should new fiscal rules prove effective it would mean achievement of the objectives in terms of fiscal discipline in a monetary union. Of course, it should be noted that institutional arrangements EMU is based on are not definitive. Starting from the experience of monetary unions in the past, it seems that the survival of the eurozone in the future depends on the willingness of member states to take steps towards establishing a fiscal union and stronger political union.

\section{References}

Анђелковић, М. (2013). Улога и значај фискалних правила у стабилизацији јавних финансија. Зборник радова Правног факултета у Нишу 65 (LI). 181199

Анђелковић, М. (2009). Усавршавање метода буџетирања - пут ка рационализацији јавне потрошње. Зборник Праавног факултета у Нишу 53. $103-123$

Димитријевић, М. (2009). Хармонизација пореза у Европској унији очекивања и резултати, Право и привреда 5-8 (XLVI). 284-295

Eijffinger C. W. S., Haan De J. (1999). European Monetary and Fiscal Policy. London: Oxford University Press 
Feldstein,M. (2012). The Failure of the Euro: The Little Currency That Couldn't. Foreign Afairs Jan/Feb. 105-116

Grauwe de P. Економија монетарне уније, Сремски Карловци; Нови Сад: Издавачка књижарница Зорана Стојановића

Grgić, M., Bilas, V., Šimović, H. (2006). Financijska liberalizacija, monetarna i fiskalna politika Europske unije. Ekonomski fakultet u Zagrebu: Serija članaka u nastajanju 14.1-22

Inman P. R., Rubinfeld, L.D. (1994). The EMU and Fiscal Policy in the New European Community: An Issue for Economic Federalism", International Review of Law and Economics. 2 (14). 147-161

Louis, J. V. (2010). The No-bailout Clause and Rescue Packages. Common Market Law Review 4 (47). 971- 986

Smits, R.(1997). The European Central Bank: Institutional aspects, Hague: Kluwer Law Internatinal

Stark, J. (2013). Lessons from the European Crisis. Cato Journal 3 (33), 541-562

Šimović, H. (2005). Fiskalni federalizam u Europskoj uniji: odnosi fiskalne nadležnosti“, Zbornik Pravnog fakulteta u Zagrebu 2 (55). 449-479 
Др Срђан Голубовић, редовни професор

Правног факултета, Универзитет у Нишу

\section{ФИСКАЛНИ АСПЕКТИ ЕВРОПСКЕ МОНЕТАРНЕ ИНТЕГРАЦИЈЕ}

\section{Резиме}

Повољна економска клима током прве деценије функционисања еврозоне прикрила је структурне слабости европске монетарне уније, али и несавршеност усвојених институциналних решења, пре свега оних који се односе на фискалну дисциплину. Оне постају видљиве са избијањем економске кризе и неспособношћу појединих земаља чланица монетарне уније да се изборе са нараслим државним дугом. Показало се да су државе са слабим макроекономским перформансама спремне да уживају све предности монетарне интеграције, али не и да преузму одговорност која је кључна за функционисање монетарне уније. Конкретно, то значи да поједине земље чланице еврозоне, чак и у периоду просперитета, нису биле у стању да очувају здраву фискалну позицију у складу са правилима европских фискалних оквира. У таквим условима, купци обвезница, које су емитовале ове државе, полазили су од претпоставке, игноришући забрану преузимања дуга, да су обвезнице емитоване од стране појединих држава чланица еврозоне подједнако сигурне као и обвезнице било које друге државе чланице, са много нижим нивоом задужености. Тиме су уједно поткопана и два кључна инструмена која треба да надоместе изостанак фискалног уједињења, а која се односе на забрану преузимања дугова (no bailout clause) и забрану финансирања дефицита држава чланица задуживањем код централне банке (monetary financing prohibition). Резултат фискалне недисциплине државе је примена тзв нестантандардних мера монетарне политике од стране Европске централне банке и увођење нових ограничења Споразумом о стабилности, координацији и управљању у Економској и монетарној унији. Посебан значај у оквиру овог Споразума даје се фискалним аспектима монетарне уније увођењем правила о уравнотеженом буџету и обавезивањем држава чланица да ова ограничења унесу у национално законодавство, уз могућност санкционисања држава која их нарушавају.

Кључне речи: Европска монетарна унија, фискални систем, Пакт о стабилности и расту и Фискални спроразум. 